\title{
Reclaiming the Idea of the University as a Possible Solution to Today's Crisis
}

Sonia PAVlenko ${ }^{* 1}$ AND CRISTINA BojAN ${ }^{2}$

$\approx$ Higher education has always been associated in one way or another with crisis. One could even argue that the university has always faced one type of crisis or another. The one debated the most is the economic crisis; however, there are many debates focusing on other types of crisis. Furthermore, all major reforms in the history of higher education (from Humboldt's reform in 19th century Prussia to the views promoted by Y Gasset against the background of the Spanish revolution, or even the Bologna Process) have arisen as a result of a crisis. Today, the global economic crisis has yet again highlighted the fact that the idea of the university, the very foundation on which it was built, is no longer present when addressing contemporary issues in higher education. Our paper argues that there is an imperative need to reclaim and reconsider the idea of the university, as this could provide a possible solution to today's crisis in higher education. Furthermore, we will attempt to show the reasons why this should occur, as well as the manner in which it could be achieved. The focus today is on too many minute, detailed aspects of higher education institutions, which are managed, evaluated, quality assured, ranked, assessed and so forth, while the global perspective on the university has been lost/ignored. Today's crisis could be used as an opportunity to reassess and re-establish a relevant idea for today's university.

Keywords: (idea of the) university; (economic) crisis; identity, legitimacy, purpose, values 


\section{Povrnitev ideje univerze kot mogoč odgovor na današnjo krizo}

Sonia Pavlenko* in Cristina Bojan

$\approx$ Visoko šolstvo je bilo vedno na neki način povezano s krizami. Lahko bi celo rekli, da so se univerze vedno srečevale s takimi ali z drugačnimi krizami. Največ se razpravlja o ekonomski krizi; kljub temu se veliko razprav osredinja tudi na druge oblike kriz. Še več, vse večje reforme v zgodovini visokega šolstva (od Humboldtove reforme v 19. stoletju v Prusiji do pogledov, ki jih je v ozadju španske revolucije zagovarjal Y Gasset, ali celo bolonjski proces) so se pojavile kot posledica kriz. Današnja globalna ekonomska kriza ponovno razkriva dejstvo, da ideja univerze oziroma temelji, na katerih je bila vzpostavljena, ni več prisotna pri obravnavanju sodobnih problemov visokega šolstva. V prispevku dokazujemo, sta nujno potrebna povrnitev ideje univerze in njen ponovni razmislek, ker bi to lahko prineslo izboljšanje po današnji krizi v visokem šolstvu. Poleg tega bomo skušali predstaviti razloge, zakaj bi se to moralo zgoditi, in način, kako bi to lahko dosegli. Danes je v ospredju vse preveč ozkih in podrobnih vidikov visokošolskih ustanov, ki se jih organizira, evalvira, jim zagotavlja kakovost, razvršča, ocenjuje itn., medtem ko je globalen pogled na univerzo izgubljen/prezrt. Današnja kriza bi lahko predstavljala priložnost za ponoven pregled in obnovo relevantne ideje današnje univerze.

Ključne besede: ideja univerze, ekonomska kriza, identiteta, legitimnost, namen, vrednote 


\section{Introduction}

The global status of higher education today might seem rosy to some eyes, but the reality is increasingly gloomy. Many debates centre on the role the university should play, or the manner in which it should relate to other stakeholders (from governments to parents and beyond). These are times that lack clarity as to the fundamental role of the higher education institution. Detailed, specific aspects are discussed, adjusted and changed, but one major aspect is constantly overlooked: the fundamental idea of the university. ${ }^{3}$ What is the university and what is its fundamental role in today's world? We argue that thinking about the university and clearly defining its idea could provide a solution to the crisis of the university.

Most universities today are forced to be more preoccupied with surviving in the short term (primarily securing enough funding) rather than being concerned with their long-term impact (more specifically, universities should not only be concerned about the percentage of their graduates who find employment within six months of graduation, but also with what sort of people their graduates will become in the long term: what kind of citizens they will be, how they will relate to the state, how they will develop as well-rounded individuals, etc.). Rankings only contribute to this problem by encouraging universities to focus on more minute, specific aspects that can be easily and quickly measured, while ignoring the more difficult to measure or longer-term aspects, such as quality of teaching (in terms of what the individual student takes away from the university experience beyond just knowledge and measurable skills, i.e., soft skills, personal development, and so on). Furthermore, the popularity of rankings leads to serious distortions in the field of higher education. Just as for Marshal McLuhan, the medium has become the message; in the case of rankings, the indicator becomes the objective (Münch, 2009; Liessmann, 2008). In turn, this leads to a dangerous lack of diversity in the field (with most universities trying to get into the top 100, or into the World Class group, etc.).

Quantitative criteria seem to take precedence over qualitative criteria (there is a preference for measuring employability, the number of contact hours, ratios and so on, rather than focusing on the real content of the educational process and its long-term effects). ${ }^{4}$ Long-term evaluation is more difficult to

3 For an in-depth discussion of this and related concept(s), see: Pavlenko, S., \& Bojan, C. (2011). The Idea of University Reshaped by the Bologna Process. The International Journal of Higher Education and Democracy, 2(1), available at: http://www.sunypress.edu/p-5232-audem-volume-2issue-1-annual.aspx

4 This also occurs in the case of research, when research output is measured by the number of papers published and their impact, and not by its impact on technology and culture, which takes longer to be measured. 
carry out than measuring more immediate results. The very concept of "Bildung" has been lost from the educational process, being replaced by competence training/development. A philosophical debate regarding the very idea of the university (instead of focusing on topics such as higher education system policy, the university's functions and role, its third-stream activities, and many other areas) could offer an easily identifiable target/goal to reach in the long(er) term, which could in turn offer a way out of the crisis situation. If we could define and/or carry out a foresight exercise regarding what the university should be as an institution in 40 years' time, we could identify a series of values that lie at the basis of the institution in the long term. The university could thus become more proactive regarding the future makeup of the world, training graduates who would be able to work in jobs that do not yet exist on the labour market, who would be the active, aware and involved citizens of tomorrow's society.

Basic concepts that used to lie at the foundation of the university have changed so much that even the idea of the university is often perceived as autarkical, and the connection between the university and society has changed for the worse. Universities no longer educate scientific and/or cultural personalities, well-rounded individuals, but rather "human capital"; training in the field has been replaced by the much narrower "competence development"; "enlightenment" is today substituted by "being informed", "collegial rule" with "specialised management", "cultural innovation" with "ISI papers" and "impact factors", and so on (Marga, 2006). This shift overlaps with the economic crisis.

Throughout the entire history of higher education, crises have been linked with shifts such as these. In some countries (such as Italy, Spain or Romania), there is a perception that the economic crisis has been used as a justification for passing legislation with stricter control of the sector, making the crisis the cause of further shifts. The idea of the university mirrors all of these crises and shifts, and it can even be used to identify possible solutions to them.

We argue that even though the university has constantly faced one type of crisis or another, today's fundamental crisis pertains to the very core of the university, i.e., its idea. In times of uncertainty, going back to the core, to the roots, provides a possible medium, or even the long-term solution, to the crisis, not just a momentary, temporary "patch".

\section{The university and crises}

A closer inspection of any text or document tackling the field of higher education (and especially universities) will, sooner or later, offer an encounter 
with the word "crisis". All major conferences dealing with higher education are bound to include lectures or presentations on the contemporary crisis connected to the university. The first part of the present paper will investigate what the actual relationship between "university" and "crisis" is, and will explore its various components.

If we start by asking the question as to whether there is a crisis related to the university in the first place, the great majority of sources in the field would hurry to agree. The media covers story after story of the global or local university crisis; international associations (such as the European University Association) organise conferences and lectures analysing the crisis the university is going through, and many states (including Romania) recognise officially (through statements made by the President or the Minister of Education) that there is indeed a real, perceivable crisis of the university that is impossible to ignore.

We should, however, start by asking how old this crisis is. Tracing the history of the co-occurrence of "university" and "crisis", one can go all the way back to the $13^{\text {th }}$ century, to the early days of the Oxford University. A well-known crisis - a brawl between "town" and "gown" - led to a number of scholars fleeing from Oxford and setting up the University of Cambridge in 1209. Jean Jacques Rousseau complained in 1772 about the quality of the universities of his time, implying that they were undergoing a major crisis:

"Today there are no longer any French, Germans, Spanish or even English, in spite of what they say: there are only Europeans. They all have the same tastes, the same passions, the same morals, because none of them has received a national moulding from a particular institution" (Rousseau, 1964, p. 620).

So there is a crisis, and there has been one in conjunction with the university for the greater part of its history. Thus, one cannot help but wonder what kind of crisis we are dealing with. A short survey of the field yields a variety of types of crisis. The one debated the most is the economic/financial crisis, which impacts the university in a very serious manner. However, one also finds a lot of discussion concerning a crisis of identity of the university, a crisis of legitimacy, a crisis of purpose, a crisis of values, a crisis brought about by globalisation, a crisis of the idea of the university, and so on. We argue that all of these various types of crisis are in fact caused by a crisis connected to the idea of the university, and that it is precisely in the idea of the university that a possible solution is to be found.

5 We understand crisis as "a time of intense difficulty or danger", or "a time when a difficult or important decision must be made", as defined by the Oxford English Dictionary (http://www. oxforddictionaries.com/definition/english/crisis? $\mathrm{q}=$ crisis). 
In 1810, Wilhelm von Humboldt lobbied for a university that would enjoy "Einsamkeit" and "Freiheit" - "solitude" and "freedom" - in all of its relationships, including those with the state (Humboldt, 1970). ${ }^{6}$ Nevertheless, despite his efforts and all of the other efforts carried out during the history of the university, the university has never been immune to unsettling economic tides. In the United States, for instance, the downturn in investment and credit markets affected, inter alia, endowment returns, access to capital, and even loan programmes for students. Reduced revenues were also accompanied by an increase in costs. However, there are a variety of ways of fighting against these tendencies; for instance, one can opt for increased student recruitment, for improved retention plans, or for greater diversification in sources of funding by building upon their individual competitive strengths, by reinforcing institutional accountability or by preparing for long-term economic recovery.

Typically, during recession periods, one expects to see increases in postsecondary enrolments, even though these occur mainly at graduate level. However, the impact on human resources is not limited only to the student body; Alex Usher predicted: "I think the economics of higher education for the foreseeable future are going to push institutions towards even more contract faculty."

The economic crisis has blurred many contour lines, even those that formerly helped to identify what a university is; however, the crisis of the identity of the university is not entirely new. During its existence - for more than nine centuries - the university has been compared to a mere religious school, to an institution of the state, to an NGO, and even to a business (think, for instance, of the emergence of the for-profit university). ${ }^{8}$

The crisis of the university does not, however, end with its identity. Many speak of a crisis of the legitimacy of the university, asking how the university acquires its legitimacy. George Fallis (2004) suggests that this is achieved through a "social contract", Jean Francois Lyotard (1993) argued that the university has legitimacy though creation (if it creates or innovates), while Andrei Marga (2006) proposed the legitimacy of the university through culture.

6 The idea of founding a new higher education institution in Prussia was born even before Humboldt's time, in 1800 , as the brainchild of Karl Friedrich Beyme and a select circle of thinkers. They put forward three possible concepts for a future institution: (a) a university specialised in "cameralistic" (economy and public administrative sciences), (b) an institution joined with a science academy, or (c) a new type of educational institution, which would be radically different from the Spezialfachhochschule (specialised higher education institution).

7 http://www.globecampus.ca/in-the-news/article/will-the-recession-affect-higher-education/ [Retrieved October 24 2010]

8 Even the Catholic Church got involved in trying to define what a university is, when Pope John Paul II issued "Ex corde ecclesia", a document that established a process for the university rather than a product. The pairing of the university and the business environment was yet again validated in 2009, when the UK Department for Innovation, Universities and Skills merged with the Department of Business and Industry. 
Nevertheless, universities have long struggled to meet almost irreconcilable demands: to be practical as well as transcendent; to assist immediate national needs and to pursue knowledge for its own sake; to both add value and question values, and so on. At the EUA conference in Palermo, Sybille Reichert ${ }^{9}$ (2010) suggested the following list of the great expectations from universities:

"Universities should...

- educate graduates to be critically minded, innovative, analytical, internationally adept, with good communication and team skills,

- train and retrain people of different backgrounds and qualifications for diverse working contexts/levels/life phases,

- produce frontier research to compete internationally for best qualified researchers and research funds and help market knowledge environment to attract foreign investment,

- produce applied research of relevance for regional and national innovation,

- solve global environmental, technical, economic, social problems (climate, energy, hunger, health, mobility, access)."

The crisis of purpose is also reflected in the manner in which universities, as well as society at large, relate to research and technology and their funding mechanisms. The pressure to yield immediate quantifiable results may alter the purpose of the university. In Drew Gilpin Faust's words: "Higher education is not about results in the next quarter but about discoveries that may take - and last - decades or even centuries." She adds: "neither the abiding questions of humanistic inquiry nor the winding path of scientific research that leads ultimately to innovation and discovery can be neatly fitted within a predictable budget and timetable" (Faust, 2009). However, the economic side is prevailing in an increasing manner in the approach often taken by university leadership. According to Faust, George Fallis (2004, in Faust, 2009) noted that "University leaders have embraced a market model of university purpose to justify themselves to the society that supports them with philanthropy and tax dollars. Higher education has the responsibility to serve not just as a source of economic growth, but as society's critic and conscience". Moreover, "universities are meant to be producers not just of knowledge but also of (often inconvenient) doubt" [...] "They are creative and unruly places, homes to a polyphony of voices. But at this moment in our history, universities might well ask if they have in fact done enough to raise the deep and unsettling questions necessary to any society".

9 http://www.eua.be/Libraries/EUA_Annual_Meeting_Palermo_2010/Sybille_Reichert.sflb.ashx 
Thus, one cannot help but wonder whether universities should have made greater efforts to predict and then expose the crisis, presenting a firmer counterweight to economic irresponsibility, or whether they have become too captive to the immediate and worldly purposes they serve, or even whether the market model has become so powerful that it is now the fundamental and defining identity of higher education institutions. Despite all of these issues, the vast majority of top positions in world rankings are held by US and UK institutions.

We argue that today the university is undergoing a crisis of values as well. "The cooperative search for truth" seems to be a widely recognised fundamental value of the university, while other values taken into consideration might be "academic freedom", "institutional autonomy", and so on. There is no definite list, as every institution is expected to create a list of its own. One possible, non-exhaustive list of the fundamental university principles (many of which can be considered values) is to be found in the Magna Charta Universitatum, a declaration signed by approximately 750 universities worldwide. In 2012, while reporting on a conference in Bologna marking the $24^{\text {th }}$ anniversary conference of the Declaration, Lee Adendorff ${ }^{\circ}$ asked rhetorically whether the Magna Charta Universitatum was still relevant. As reported by Adendorff, the conference's aim was to see whether the Declaration's list was still relevant, and whether an addendum might be needed in order for the document to better reflect today's context.

The globalisation process has also been disruptive for the university, as it no longer competes merely on the local, regional or national level, it has to be competitive on the global level, taking into account the latest, cutting-edge research and innovation, and it has to be proactive, no longer only reactive. ${ }^{11}$

Last but not least, one can also speak about a crisis of the idea of the university, as we cannot help but wonder whether one can still speak of an "idea of the university".

The German idealist movement is credited by Sheldon Rothblatt (1989) with proposing the "idea of the university". For the first time, they attempted to capture the essence of the university on a more abstract, conceptualised level, by looking at what a university should be, which roles it should fulfil, and what kind of training (and changes) it should instil upon its graduates. The

10 Lee Adendorff, Is the Magna Charta Universitatum still relevant?, in University World News, 30 September 2012 Issue No:241, available at http://www.universityworldnews.com/article. php? story $=20120927080003671$

11 For a more detailed discussion of the interaction between the university and the globalisation process, see: Bojan, C., \& Pavlenko, S. (2011). University Rankings. Anglo-Higher Magazine, 3(1), 5-6, available at: http://www.anglohigher.com/magazines/viewpdf_mag/101/38 
Humboldtian idea of the university (Humboldt, 1970) combined teaching and research, solitude and freedom; the research university (Perkins, 1973) chose to focus mainly on research activities; the entrepreneurial university (Clark, 2001, 2004) strived for professionalised management and the diversification of activities, proactiveness rather than just "reactiveness" to changes and opportunities. The idea of the university became so varied that, at the end of the $20^{\text {th }}$ century, Habermas (2003) argued that one could no longer speak about a sole idea of the university. However, given the recent changes brought about by the Bologna Process (1999-2010) and by the European Higher Education Area (2010-...), we cannot help but wonder whether there is a new emergent idea of the university resulting from these reform processes.

It is estimated that the economic crisis triggered an increase in the number of fixed-term staff ${ }^{12}$ to almost three-quarters of the total number of academics, with foreseeable consequences for a wide range of issues, from academic freedom all the way to financial security.

In Europe, the effects of the financial crisis vary widely. It has triggered a reassessment of the way in which public funds are allocated. In times of plenty, there was enough to go around to most actors (or at least to a large number of actors); however, in times of economic scarcity, governments must establish priorities and decide not only who needs the money the most, but which expenditure is the most important.

On the European level, there are three major trends that have been developing in the last few years: countries that have chosen to increase funds for higher education, countries that have decreased the amount of funds, and an empty category (for countries with a constant budget allocation). The manner of funding and funding choices made by governments have effects on the movement of competencies and human resources around European countries (for example: Austria-Germany, students going to study in England or Germany even though there are high study fees in England!). Funding trends should be related to inflation, which paints quite a different picture of funding trends in Europe. Furthermore, the crisis has also been seen as a kind of "Trojan horse", being used by governments to pass tough reforms (Italy, Spain, Romania). Thus, the crisis presents an opportunity for a re-evaluation of the direction in which higher education systems are heading.

Given all of the above, one has to ask: How does the state relate itself to the university/higher education system? The countries that have invested

12 See for instance http://download.ei-ie.org/Docs/WebDepot/20100903_IHERC_fullreader_ en.pdf and http://www.ei-ie.org/highereducation/en/articleshow.php?id=153\&theme=higheredu cation 
in higher education see it as a possible solution to the crisis (as [higher] education-generated innovation, which in turn generates development, which in turn leads to economic growth and ultimately to improved general welfare), while the other group of countries seem to see it as a burden on the state budget (to be reduced as far as possible).

So what implications does all of this have for institutional autonomy, for the civic role of the university, for university's third mission, for the internal structure of the university and for many other aspects? The idea of the university mirrors all of these crises, but can also offer possible solutions to them.

For the purpose of the present paper, we assume a hierarchy involving the concepts of the idea, ideal, mission, functions and roles of the university. The most abstract of these is the idea. In itself, it can never be reached or realised. The Humboldtian idea of the university was something that was aimed at but never achieved (Ash, 1997). One can only reach as far as the level of the ideal, at a less abstract level of thought. Starting from the idea (once it is clearly defined), one can build various models of higher education institutions (useful illustrations of this process are the Humboldtian university - the research university emerging from the Humboldtian ideal - and the Napoleonian university or the civic university). The model can in turn be transferred to the mission, vision and functions of the university, the latter being situated at the most concrete level of the concepts mentioned above.

If, at the beginning of the $19^{\text {th }}$ century, there were only two main university models (based on clear ideals and ideas, namely the Humboldtian university and the Napoleonian university), today we can speak about a great diversity of types of universities that could be classified in a variety of ways (using distinct criteria). University models are abundant, and range from the World Class University to the multiversity, the online university and many more. This diversification was so intense in the $20^{\text {th }}$ century that Jürgen Habermas (2003) argued that one cannot speak anymore about an idea of the university. One important function of the university is to keep up with the changes in society (or even to anticipate them and act accordingly), and this ability should be found on all levels of the institution. The university should be an exemplary way of living embodied in an institution. However, Habermas argued that institutions no longer have an idea at their core, as this would limit the lifeworld shared in an intersubjective manner by the members of the institution (ibid., p. 74). We argue that today there is a stringent need for an idea, as it would instil coherence (and not convergence) in highly diversified systems as well as within individual institutions.

The main changes in the field of higher education came about at the turn of the centuries. The beginning of the $19^{\text {th }}$ century witnessed the birth of 
the Humboldtian and Napoleonian models, the beginning of the $20^{\text {th }}$ century hosted a renewed debate on the idea of the university (and the changes it underwent as a result of conflicts and geopolitical changes), while the $21^{\text {st }}$ century welcomed a process that would shape (at least) European higher education for the foreseeable future, namely the Bologna Process. However, there is one aspect that differentiates the manner in which the idea of the university was approached in the previous two centuries in comparison to our century: the Humboldtian tradition, as well as the debates of the $20^{\text {th }}$ century, have a topdown approach, starting from an abstract level and moving to more specific levels (i.e., once you clarify and define an idea, you can then establish a mission, vision and functions for the university, which are then further translated into its actual roles and connections), while the Bologna Process is a bottom-up approach, starting from the concrete roles of the university but failing to move to a more abstract level of the idea or ideal. Even if many still argue that "the idea of the university cannot possibly be completely dead", the Bologna Process (as well as the European Higher Education Area that follows it) has not (yet?) offered an identifiable, coherent ideal, nor an idea, for the (European) university.

We argue that this could be built through a joint effort of exploration and identification of fundamental values, on one hand, and of what the university should be in the long term (25-50 years), on the other. Possible elements belonging to such an idea could be glimpsed in documents such as the Magna Charta Universitatum or the European Cultural Convention. Starting from the premises that the future of mankind depends on developments that will take place in "centres of culture, knowledge and research as represented by true universities", ${ }^{13}$ that universities must serve society as a whole and that "universities must give future generations education and training that will teach them, and through them others, to respect the great harmonies of their natural environment and of life itself", ${ }^{14}$ the Magna Charta Universitatum proclaims four fundamental principles (academic freedom, the inseparability of teaching and research, freedom of research, and the basic aim of the university is universal knowledge) that must "support the vocation of universities", ${ }_{15}$ and offers four means for attaining these goals. These principles offer a solid basis for further development of a contemporary idea and ideal of the university.

Nowadays, universities face a variety of expectations, but both the Bologna Process and the European Higher Education Area have failed to meet these expectations, as they have never been gathered coherently under a unified

13 Magna Charta Universitatum, p. 1, available at http://www.magna-charta.org/library/userfiles/ file/mc_english.pdf

14 idem

15 idem 
vision that might be universally shared. A jointly developed vision, clearly communicated and widely shared, could have the potential to rise to the level of the ideal for the university of the $21^{\text {st }}$ century. Other centuries have had clearly defined ideals for the university (albeit called by different names), even if they might not have had an idea at a more abstract level than the ideal. So, even though the Bologna Process has triggered yet another re-assessment of the contemporary ideal of the university, at least on the European level, the actual ideal is not defined, despite being constructible starting from the common changes brought about by the Bologna Process and the transparency it has promoted.

\section{Conclusions}

The Bologna Process has triggered a re-assessment of the idea of the university, but the process stopped before reaching its core level. The top-down Humboldtian approach is in stark contrast to the bottom-up approach of the Bologna Process. We argue that the process should be continued until the basic nature of the university today is defined (and transparently comparable). A conscious taking charge of the idea of the university is mandatory (as well as its translation not only in the mission statement, but also to all of the minute day-to-day processes that take place within the university). Thus the university could take on the medium-term and long-term role of building the society as well as the state and even the world - of tomorrow, rather than focusing only on short-term results (such as employability). Ultimately, Bildung cannot be measured through an immediately applicable indicator (through metrics of scientometrics); it can be best assessed through the general welfare of society in the long term (i.e., not immediate effects, but long-term effects).

A time of crisis can be seen both as an advantage and a disadvantage. On the one hand, it brings about change, forcing the university to think ahead and to adapt, react and change according to the times, while, on the other hand, it lacks predictability, forcing many institutions to take leaps in the dark or to make, at best, "educated guesses" about their future. Today's economic crisis may be used as an opportunity to identify the fundamental idea of the university (as appropriate to today's times), the basic nature of higher education (focusing not on the mundane details, but on the core of the institution), which would in turn provide a long-term solution to the crisis. If we define what the university is in its essence, what its role should be, it then becomes clear what its functions should be, and which indicators should be used for assessing it. 


\section{References}

Ash, M. G. (1997). Mythos Humboldt, German Universities. Past and Future. Crisis or Renewal?. Providence, Oxford: Berghahn Books.

Barnett, R., \& Maxwell, N. (Eds.) (2008). Wisdom in the University. London: Routledge.

Clark, B. R. (2001). The Entrepreneurial University: New Foundations for Collegiality, Autonomy, and Achievement. Higher Education Management, 13(2), 9-24.

Clark, B. R. (2004). Sustaining Change in Universities: Continuities in case studies and concepts.

London: SRHE/OUP.

Fallis, G. (2004). The Mission of the University. Higher Expectations for Higher Education,

Government of Ontario.

Faust, D. G. (2009, September $1^{\text {st }}$ ). The University's Crisis of Purpose. The New York Times. Retrieved from http://www.nytimes.com/2009/o9/o6/books/review/Faust-t.html?pagewanted=all\&_r=o

Habermas, J. (2003). Die Idee der Universität - Lernzprozesse. In Eine Art Schadensabwicklung (pp. 73-97). Frankfurt am Main: Suhrkamp.

Liessmann, P. K. (2008). Theorie der Unbildung. Wien: Zsolnay Paul Verlag.

Lyotard, J. F. (1993). Condiția postmodernă. Raport asupra cunoaşterii. Bucureşti: Editura Babel.

Marga, A. (2006). The Cultural Legitimacy of the European University. Cluj-Napoca: Cluj University Press.

Maxwell, N. (2007). From Knowledge to Wisdom: The Need for an Academic Revolution. London Review of Education, 5, 97-115.

Münch, R. (2009). Globale Eliten, lokale Autoritäten: Bildung und Wissenschaft unter dem Regime von PISA, McKinsey \& Co. Frankfurt a.M.: Suhrkamp.

Perkins, J. A. (1973). Organisation and Function of the University. In J. A Perkins (Ed.), The University as an Organisation (pp. 3-14). New York: McGraw Hill

Rothblatt, S. (1989). The Idea of the Idea of a University and its Antithesis. Conversazione, Bundoora:

La Trobe University.

Rothblatt, S. (1997). The Modern University and Its Discontents: The Fate of Newman's Legacies in Britain and America. New York and Cambridge: Cambridge University Press.

Rousseau, J. J. (1964). Considération sur le gouvernement de Pologne et sur sa reformation projetée. In J. Fabre (Ed.), Oeuvres completes. Paris: B. Gagnebin and M. Raymond. Rüegg, W. (Ed.) (2004). A History of the University in Europe, Vol. III: Universities in the Nineteenth and Early Twentieth Centuries. New York: Cambridge University Press. von Humboldt, W. (1970). Über die innere und äußere Organisation der höheren wissenschaftichen Anstalten in Berlin. In E. Müller (Ed.), Gelegentliche Gedanken über Universitäten (pp. 267-283). Leipzig: Reclam. 


\section{Biographical note}

Sonia Pavlenko, Dr., is a higher education researcher at the Centre for University Development, Babeş-Bolyai University, Cluj-Napoca, Romania. She earned her PhD from Babeş-Bolyai University with a thesis on the "Idea of the University". She spent part of her $\mathrm{PhD}$ as a Chevening scholar at University of Oxford, UK. Her postdoctoral research investigated aspects connected to leadership and governance in Romanian higher education. Her work focuses on higher education philosophy and policy, on issues relating to international rankings as well as leadership and governance in universities, topics on which she has published extensively.

Cristina Bojan, Dr., is assistant lecturer at the Faculty of European Studies, Babeş-Bolyai and Head of the Department of European Studies of the German line of study. Her PhD was in the field of higher education philosophy and policy, and most of her publications are in this field. Her area of interest is in philosophy of education, education policy, history of ideas, and cultural studies. She has held scholarships at: Paris Lodron University Salzburg (2001); Leipzig University (2003); Westfalische Wilhelms University Münster (2003, 2006); and completed the International Parliamentary Internship Program, organised by the Deutscher Bundestag (2005). 